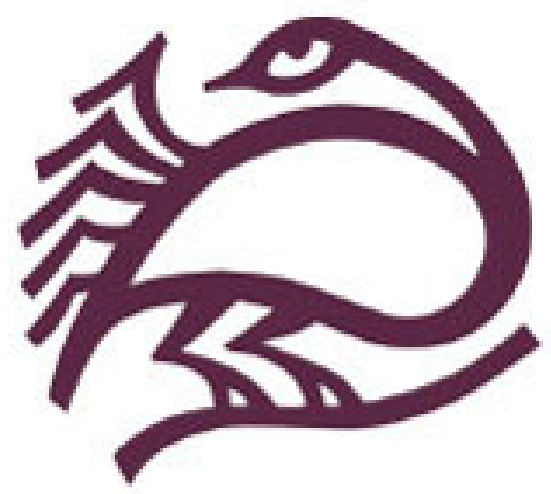

The Vicissitudes of the 1948 Historiography of Israel Author(s): Ilan Pappé

Source: Journal of Palestine Studies, Vol. 39, No. 1 (Autumn 2009), pp. 6-23

Published by: University of California Press on behalf of the Institute for Palestine Studies

Stable URL: http://www.jstor.org/stable/10.1525/jps.2010.XXXIX.1.6

Accessed: 28/03/2014 10:30

Your use of the JSTOR archive indicates your acceptance of the Terms \& Conditions of Use, available at http://www.jstor.org/page/info/about/policies/terms.jsp

JSTOR is a not-for-profit service that helps scholars, researchers, and students discover, use, and build upon a wide range of content in a trusted digital archive. We use information technology and tools to increase productivity and facilitate new forms of scholarship. For more information about JSTOR, please contact support@jstor.org. 


\title{
The ViCissitudes OF THE 1948 HISTORIOGRAPHY OF ISRAEL
}

\author{
ILAN PAPPÉ
}

\begin{abstract}
Arguing that history writing is a dialectical process fusing ideological agenda and political developments with bistorical evidence, the author analyzes the two major transitions experienced by the Israeli historiography of the 1948 war: from the classical Zionist narrative to the "New History" of the late 1980s, and from the latter to the emergence of a "neo-Zionist" trend as of 2000. While describing the characteristics of these trends, the author shows how they are linked to concurrent political developments. Most of the article is devoted to an examination of the neo-Zionist historians who have emerged in recent years, based on their previously untranslated Hebrew works.
\end{abstract}

DESPITE THE SCIENTIFIC OBJECTIVITY and scholarly neutrality generally claimed for professional historiography and the academic enterprise, few sociologists of knowledge would contest the fact that history writing is based on choices and decisions. Indeed, a historical narrative is far more than a simple sequencing of events, but rather a way of extracting a plot out of collated facts, requiring historians to make decisions about what to include, exclude, emphasize, and how to structure the narrative. This being the case, it is inevitable that current political realities influence the agendas and orientations of professional historians, especially when the subject matter involves a disputed land, and even more so when the narrative is seen as playing a crucial-even existentialrole in that land's ongoing struggle and self-image.

Such is the case of Palestine, and particularly the 1948 war that brought Israel into being. Testifying to the volatility of the historical narrative, Israeli historiography has undergone two major transitions in less than two decades. The first was from the classical Zionist narrative of a heroic Jewish struggle for survival against all odds that ended in the voluntary flight of the Palestinians from much of Palestine, to the "New History" narrative of the 1980s. This new narrative fundamentally challenged the earlier version, but around the year 2000 , it gave way to what I will call the "neo-Zionist" narrative that reembraced the spirit, if not the details, of the original Zionist version. In essence, it was a

\footnotetext{
ILAN PAPPÉ, an Israeli historian and chair in the Department of History at the University of Exeter, is the author of a number of books, including A History of Modern Palestine: One Land, Two Peoples (Cambridge University Press, 2004), and The Ethnic Cleansing of Palestine (Oneworld Publications, 2006). This article was first presented on 23 November 2008 as part of the Institute for Palestine Studies-Mansour Armaly panel at the annual Middle East Studies Association conference held in Washington, DC.

Journal of Palestine Studies Vol. XXXIX, No. 1 (Autumn 2009), pp. 6-23, ISSN: 0377-919X; electronic ISSN: $1533-8614$ (c) 2010 by the Institute for Palestine Studies. All rights reserved. Please direct all requests for permission to photocopy or reproduce article content through the University of California Press's

Rights and Permissions website, at http://www.ucpressjournals.com/reprintInfo.asp. DOI: jps.2010.XXXIX.1.6.
} 
transition from adherence to the national consensus, to a recognition among certain elites of its many contradictions and fabrications, to a rejection of the post-Zionist questioning of the national consensus.

Such changes do not occur in a vacuum but are closely related to the politics and societal currents of the time; history is not just facts but a dialectical process of fusing ideological agenda with historical evidence.As I will explore below, the transitions were also linked to the vicissitudes of the peace process and closely reflect its development and demise.

The time that elapsed between the challenge posed by the New Historians, also commonly referred to as "post-Zionists," and their disappearance from the scene was short, less than two decades. The reason for this brevity is doubtless to be found in the fact that the 1948 war is not only a story closely linked to current politics but also a foundational myth. According to Louis Althusser, ${ }^{1}$ foundational myths are those most easily absorbed by society and according to which the social order is structured and maintained. They provide the narrative that justifies the existence of the state, and as long as they remain relevant to the existing social order, they retain their force. In the case of Israel, of course, and despite the appeal and prominence enjoyed by the post-Zionist discourse for a time, the social order had not changed, which could explain why society so quickly reverted to its long-held beliefs. And because the history of the 1948 war is also linked to matters of war and peace, to relations with the Palestinians, and therefore to the entire future direction of the country, any professional academic conclusions about it were and are extremely relevant for the political scene.This was recognized by the scholars themselves, as well as by the politicians involved in the peace process. ${ }^{2}$

A word is in order regarding the methodology used here. Deciphering what lies behind the decision to produce a certain narrative is beyond the capacity of sociology or, for that matter, the archeology of knowledge. Therefore, I have limited my attempt to pointing to the way in which changes in the political atmosphere are reflected in the narrative of the works produced by practicing historians focused on 1948. According to the ethos of academia, the work of these historians should in principle not be affected by changes in public mood or general political orientations. However, the case study I present in these pages-the Israeli historiography of 1948-indicates that, in this conflict especially, the writing of history absorbs and represents ideological disputes and political developments as much as any other cultural medium. The difference is that other media or discourses do not pretend to be objective or neutral.

\section{Historiography and Society: Post-Zionism and Neo-Zionism}

The "new narrative" of the 1948 war that appeared in the late 1980s included works of Israeli academicians described as New Historians and "critical sociologists," though the latter did not confine themselves to 1948 but covered a longer historical time span. ${ }^{3}$ What they had in common was a willingness to 
look at the past and present Israeli reality through non-Zionist eyes. While they included relativists and positivists and came from a variety of disciplines, they shared a common liberation from the Zionist metanarrative, and many of the chapters they rewrote echoed the Palestinian version of history. Despite their frequent designation as post-Zionists, a number of them were actually liberal or critical Zionists, and their critique of Zionism was reflected in the works of artists, playwrights, filmmakers, journalists, writers, poets, and cultural producers in general. They operated with a high visibility in the 1990 s before they disappeared at the end of that decade.

The political background of their emergence is found in a chain of events that began with the 1982 Lebanon War and was reinforced by the outbreak of the first Palestinian uprising in 1987. These events moved Israeli society as a whole into a more introspective phase regarding its relationship with the Palestinians. Politically, the new outlook translated into a willingness, however reluctant or tentative, to take part in the Middle East peace process, culminating in the Oslo Accord in 1993 and followed by the signing of the bilateral peace agreement with Jordan in 1994. With the assassination of Israeli prime minister Yitzhak Rabin in 1995, the sanguine optimism began to wane.A creeping pessimism set in, along with a growing distrust in the Palestinians, a move to the right, and a scaling back of Oslo's implementation and goals. At the same time, the popular appeal of the New Historians, or their post-Zionist manifestation, began to wane gradually.

What brought the "post-Zionist decade" - and the historiographical debate on 1948-to a definitive end was the outbreak of the second intifada in late September 2000.Almost immediately, a reinvigorated Zionist consensus, which had somewhat eroded at the height of the Oslo days, reasserted itself with force. Public discourse in Israel was reshaped along strictly consensual lines. Without doubt, the immediate reembrace of the Zionist consensus was greatly facilitated by the fact that Israel's mainstream media uncritically accepted and widely disseminated the government's propagandist version of Yasir Arafat and the PLO as not only the initiators of the second intifada but also as fully to blame for the failure of the 2000 Camp David summit. In the eyes of Jewish society and its political elite, Israel had done all it could to achieve peace but was met with extremism and intransigence, forcing the government to go from peace to war. The Palestinians had proved themselves to be enemies, thereby justifying the brutality of the Israeli response to the intifada and the closing of the public mind.Ariel Sharon's election by a wide margin in February 2001 confirmed the magnitude of the public support for the new policies, while the events of 9/11 facilitated the government's depiction of Arafat as an archterrorist associated with Bin Laden and of Israel's response to the uprising as part of the global war on terror. As in the past, the media and academia were the principal agencies providing "professional" and even "scholarly" scaffolding for these interpretations. ${ }^{4}$

Thus, just as the atmosphere and politics of the early 1990s had been conducive for local historians to open a window to the Palestinian narrative and 
even contemplate acceptance of some of its main claims, so the changed conditions after 2000 provided fertile soil for a new generation of historians to entrench and barricade the narrative behind a wall of negation and fortify the collective identity in the face of renewed struggle. ${ }^{5}$

It is important to emphasize that while the traditional Zionist consensus was immediately restored and reembraced, the new historiographical narrative, which had already begun to assert itself prior to 2000 , did not exactly reproduce the traditional Zionist narrative; it is not only history, but also historiography, that does not repeat itself. What emerged instead was a new-old narrative, updated to fit the shifting political realities on the one hand and to take into account and absorb the new information coming out of the Israeli archives on the other.

The new historiography was Zionist in its ideological orientation, its mode, its coloration, but it avoided the omissions, distortions, and denial of facts that had characterized the traditional Zionist version. The post-Zionists and New Historians, whose work had been based on Israeli archival sources to the extent that these were accessible at the time, had brought to light new facts concerning expulsions, massacres, and other war crimes committed in 1948 that the neo-Zionist generation could not ignore. Most important for their emergence was the release in 1998 of major new documentation from the Israel Defense Forces (IDF) and Haganah archives, allowing professional historians in Israel to see with their own eyes in government documents the magnitude of the 1948 ethnic cleansing. Even "nationalist" and Orientalist historians, who had scorned Arab or Palestinian sources and relied exclusively on Israeli sources, could no longer deny the massive and intentional expulsions. ${ }^{6}$

Thus, from a purely factual standpoint, the neo-Zionist version of 1948 did not differ significantly from that of the post-Zionists or New Historians.

The difference was in the response or interpretation of

What the New Historians saw as human and civil rights abuses or even atrocities and war crimes are treated in the new research as normal and sometimes even commendable behavior by the Israeli military. the facts. What the New Historians saw as human and civil rights abuses or even atrocities and war crimes are treated in the new research as normal and sometimes even commendable behavior by the Israeli military. What the post-Zionists interpreted as shameful chapters in Israeli history are rejustified in the new research. ${ }^{7}$

From the neo-Zionist perspective, acceptance of the factual claims of the New Historians was accompanied by the categorical rejection (shared by the Israeli public at large) of the contemporary moral implications that the New Historians drew from their findings of Israel's crimes in 1948, first and foremost the dispossession of the Palestinians. The neo-Zionists did not merely reject the interpretation of the post-Zionists but attacked them on moral grounds for dangerously undermining the legitimacy of the state.This approach is succinctly articulated in the journal Techelet, where some of Israel's leading practicing historians publish regularly. It is a mouthpiece for what in Israel is called the "New Right," which does not actually represent a rightist position but rather a consensual one, also accepted by historians of the Left. 
Honest readers [of the work of the New Historians] cannot deny most of the facts presented by these historians about Zionism's policies in the past ... and yet it seems that the conclusion that these historians were looking for are aimed at undermining the very legitimacy of the fathers of the nation, who are not alive anymore.... We cannot underrate the perils of such an attack.... No nation would be able to keep its vitality if its historical narrative were to be presented in public as morally defunct. [Moreover,] the novelty of what the New Historians did was in the perspective not the facts ... these are not facts, but deep moral assessments. ${ }^{8}$

The above quote sums up the essence of the neo-Zionist response to the New Historians: acceptance of the basic facts they unearthed while castigating them on moral grounds. Indeed, what amounted to a distribution of labor developed among the scholars working within a neo-Zionist perspective on the 1948 events. One group undertook to challenge the moral underpinnings of the critical historiography and the other group focused on reexamining the factual evidence from which a new-old Zionist narrative of the 1948 war could be reconstructed in a way that would reflect the new mood in presentday Israel.

\section{The Critique of the New Historians and the Moral Debate}

Paradoxically, even as the post-Zionist approach-and with it, the critical spirit within Israeli society-was totally silenced and marginalized with the outbreak of the second intifada, the attack on the New Historians (except for Benny Morris) showed no sign of abating. Even in its greatly diminished condition, the critique of Zionism from within Jewish society continued to be depicted as a grave danger to the Jewish character of the state. From 2000 onward, questioning the national narrative in general and that of 1948 in particular was perceived as an ideological threat that needed to be countered professionally by academia at home and abroad. ${ }^{9}$

The critique of the New Historians-which had raged since their first emergence-thus continued even as their influence disappeared, but on new grounds that reflected neo-Zionism's preoccupation with demonstrating the "morality" of the Zionist venture. Whereas in the early years of the post-Zionist challenge, the argument was about the facts, it has now shifted to "exposing" what lies behind the critical history and sociology that emerged in Israel as of the late 1980s. The earlier response was epitomized by Efraim Karsh, whose "fabricating history" allegations were later published in his book of the same title, ${ }^{10}$ but who made no mention of morality. In fact, the above-mentioned article in Techelet explicitly rebuked Karsh for failing to morally and ideologically confront the New Historians while going to battle against "undeniable facts." ${ }^{11}$ The editors of the journal concluded that Israeli academia could not 
permit the New Historians to set the research agenda on 1948, another critique absent from the earlier Zionist response.

The moral battle was waged especially outside Israel, where the message of the post-Zionists had made more lasting inroads. A number of books representing the neo-Zionist perspective on the 1948 war appeared in the United States in the years following the eclipse of the New Historians, but the best example is a collection edited by Anita Shapira and Derek J. Penslar, titled Israeli Historical Revisionism: From Left to Right (Frank Cass Publishers, 2003). In their introduction, the editors declared that the revisionists, excluding Morris, had been waging an attack on Zionism itself, ${ }^{12}$ but the moral battle was led with the greatest passion by political philosopher Michael Walzer. ${ }^{13}$ Presenting Zionism as a liberation movement of exceptional morality, Walzer characterizes the debate over the 1948 war as an existential battle against the forces of evil. He does not confront the facts but uses the discourse of "complexity" to stifle the debate.The dispossession of almost a million Palestinians, the control through occupation, and the discrimination against almost another 5 millions are all described as complex issues. ${ }^{14}$ In a similar vein, Zionist historian Daniel Gutwein of Haifa University, after arguing that there was nothing new in the factual claims of the New History, sees Zionism as facing formidable enemies, including postmodernists and nihilists bent on privatizing the collective sacred national memory for their own selfish, if not perverse, interests. ${ }^{15}$ Others even accuse the New Historians of outright treason. ${ }^{16}$

Before examining the works of the neo-Zionist historians, a few words should be said about Morris, one of the most important of the New Historians, who, following what he described as his "turning point" in 2000 , could be said to embody both of neo-Zionism's hallmarks: its positivism and (in his political writings and interviews) its moral justification of the 1948 war. Morris had never been a post-Zionist nor had he ever shared the moral or ethical reading of the facts he uncovered. At the same time, he did not shy away from providing evidence damning to the Zionist narrative. His book, The Birth of the Refugee Problem, 1947-1949 (Cambridge University Press, 1987), provided the first systemic evidence based on IDF sources of major expulsions during the 1948 war. When the new documents were released in 1998 showing the expulsions to be far more premeditated, systematic, and extensive than had been shown in the more limited documentation available a decade earlier, Morris, ever the positivist, undertook what he referred to as the correction of a mistake and revised and expanded his book to reflect the new evidence. By the time the new edition was published in 2004, the new intifada was well underway and the revelation of what would earlier have been seen as "damning" new information about 1948 fused conveniently with the closing of the public mind with regard to the Palestinians in the wake of the uprising. In the new atmosphere, not only were Israel's brutal military operations against the Palestinians during the new intifada seen as justified, but so was their systematic expulsion in 1948. Morris, who had earlier been wrongly accused of being an "Israel hater" and a post-Zionist, now set an example for the neo-Zionists and was ideally situated to 
provide hindsight justification for the 1948-49 expulsions. In an interview with Ha'Aretz published on 9 January 2004, he provided the ultimate justification for the ethnic cleansing in 1948: "Without the uprooting of the Palestinians, a Jewish state would not have arisen here." ${ }^{17}$ Furthermore, he faulted Ben-Gurion for failing to "cleanse" the "whole Land of Israel, as far as the Jordan River," which "would have stabilized the State of Israel for generations." 18

\section{The New Face of Professional History Writing}

Morris's description of the ethnic cleansing of 1948 as an act of self-defense, a choice "between destroying or being destroyed," and his insistence that the 1948 war was one of those "circumstances in history that justify ethnic cleansing"19 characterizes well the underlying spirit of neo-Zionist work on 1948 within the Israeli academy ${ }^{20}$ and in many recent collections on the war. ${ }^{21}$ In some of the new works, the moral defense of the war approaches messianic proportions. The introduction to one of the major collections on the war, the two-volume Israel's War of Independence, 1948-1949 (in Hebrew; Israeli Ministry of Defense Publications, 2004), by its editor, Alon Kadish, is a good example. Kadish, a former head of the Hebrew University's history department, almost theologizes the 1948 Jewish war effort, referring to the outcome as a victory of the "just" over the "unjust" in a battle that averted a second holocaust, ${ }^{22}$ and to the year 1948 as the last link in the chain that "completed the redemption of the land and the return of the Jews to their homeland, as well as the renewal of their independence on the land." ${ }^{23}$ In general, Kadish's collection, with its scores of articles focusing on military dimensions of the war, exemplifies well the mix of messianic Zionist discourse and archival, positivist reconstruction that typifies the neo-Zionist approach. One might even suggest that it was thanks to the combined emphasis on messianic fulfillment and existential threat that the Judaization and de-Arabization of Palestine (not just in the areas earmarked for the Jewish state in the 1947 UN partition resolution, but well beyond) is now fully recognized and morally justified as the principal goal of the Zionist leadership in 1948.

These elements (divine promise and existential survival) had likewise constituted a crucial subtext of the "old history" of 1948 written before the New Historians, though the old history, as already indicated, tended to be more discreet on such matters as expulsions and massacres. Another way in which the old mainstream Zionist historians differed from the neo-Zionist historians (and also from the New Historians) was that they were generally not professional historians but journalists and pundits who were part of the political elite. Still, one of the main practitioners of the neo-Zionist narrative wrote an entire book to vindicate the early historiography of 1948 as valid and scholarly. ${ }^{24}$

Many of the neo-Zionist historians of 1948 are postgraduates or newly minted scholars recently inducted into the community of professional historiography. They not only have access to the documents released from the IDF archives in 1998 but have also been entrusted with selective and top-secret material 
that never would have been shown to scholars suspected of being critical of Zionism. Significantly, much of their work, which is in Hebrew, is published by the Israeli Ministry of Defense. The fruit of their efforts is quite voluminous and indicates both a new discourse and a fresh choice of subject matter, which generally moves away from the human dimensions of the war and toward its military aspects, with well-trodden military campaigns being reexamined from every possible angle. Modern themes such as Jewish civil society in wartime became favorites, redirecting the research away from the victimization of the Palestinians to tales of the heroic steadfastness of the Jewish community in $1948 .{ }^{25}$ A number of works blamed the Palestinians for their fate, following the lead of Morris post-2000, ${ }^{26}$ as well as of established scholars who had steered clear of the New History, such as Yoav Gelber. ${ }^{27}$ But while the "blaming the Palestinians" theme is often a subtext in these works, sometimes it is explicit, as in the case of Tamir Goren ${ }^{28}$ who focused specifically on the responsibility of the Palestinians for their exodus from Haifa. Other subject matters include the recruitment of Jewish volunteers abroad and their fate; ${ }^{29}$ the role played by the settlements; ${ }^{30}$ logistical problems of infrastructure, politics, and the military; ${ }^{31}$ and the costs of the war and the economic factor. ${ }^{32}$ In the dominant mood of post-2000, Palestinian action and resistance in 1948 are recast in terms reflecting modern-day terrorist organizations and actions. ${ }^{33}$ Some of the new research also reverts back to subject matters more characteristic of the old Zionist narrative, such as the reinvention of 1948 as primarily a war of liberation against the British. ${ }^{34}$ This work also reaffirms the Zionist claim of "purity of arms," though this time vis-à-vis the British forces instead of the Palestinians (while postZionists focus on demolishing this myth).

A number of the above-mentioned works appear in Kadish's edited twovolume set, Israel's War of Independence, whose introduction was discussed earlier. (The title is typical of neo-Zionist historiography, which has abandoned the neutral term "the 1948 war" used by the New Historians in favor of either the "war of independence" or "war of liberation.") Taken as a whole, the Kadish collection illustrates many of the hallmarks of neo-Zionist historiography. Part of the new strategy, especially with regard to the expulsions, is to emphasize them as common if not inevitable occurrences in war and treat them from an almost technical standpoint. This is effectively demonstrated in Haifa University geography professor Arnon Golan's article bearing the wonderfully bland title "The Reshaping of the Ex-Arab Space and the Construction of an Israeli Space (1948-1950)." Golan, who had earlier taken a leading role in trying to refute the works of New Historians, here abandons his earlier denial of the ethnic cleansing to write:

The policy carried out with regard to the occupied Arab villages was their total destruction and the expulsion of the villagers who remained.The action was always implemented in keeping with the strictest interpretation of Plan Dalet ... There were also the phenomena of vandalism and revenge. ${ }^{35}$ 
The facts are there, recounted matter of factly, without any hint of moral discomfort. Golan explains that both sides exercised the same policy of expulsion, typical in times of war. Still, he apparently felt compelled to offer some justification through a return to a theme he had developed in his 1993 doctoral dissertation: because 1948 had produced both Arab and Jewish refugees, the issue was one of "equal victimhood." 36 It bears emphasis that, in contrast to most writers claiming equal victimhood with reference to the Jewish refugees from Arab countries, Golan specifically refers to the few hundred Jews whose settlements in what became the West Bank were dismantled and to the residents of the Jewish quarter in the old city of Jerusalem, all areas annexed to Jordan by prior Jewish consent. Like Morris in his new incarnation, Golan regrets the absence of a more effective and coordinating hand in the division of the spoils of war resulting from the systematic Israeli pillaging of Palestinian property, houses, lands, and bank accounts, but points out that the dispossession of the Palestinians was the only way to make possible the absorption of so many Jewish immigrants after the 1948 war. $^{37}$ His approving treatment of Israel's antirepatriation policy (also now condoned by Morris) ${ }^{38}$ is another aspect of this.

Not surprisingly, many of the chapters of Israel's War of Independence reproduce the basic outline of events recounted by the New Historians, albeit with very different results. Dani Hadari's chapter, for example, emphasizes (as do the New Historians) Plan Dalet's importance in precipitating the ethnic cleansing of Palestine. ${ }^{39}$ Although Hadari does sanitize the terminology (he refers to the part of the plan detailing instructions to destroy Palestinian villages merely as "an important military mission" ${ }^{40}$ ), he makes no attempt to conceal actions that traditional Zionist writers would have preferred to avoid. For example, not only does he write that the Jewish troops rarely honored Plan Dalet's offer of surrender to Palestinian villages that had been promised immunity, he also commends the army for its harsh interpretation of the plan, ascribing it to the army's known propensity to "take the initiative"-litol yozman. ${ }^{41}$

He even highlights the case of Umm Zayant, a village

While the term "etbnic cleansing" is almost never used by the neo-Zionists, "de-Arabization" has been adopted, a term that would have been unthinkable in pre-1948 classical Zionist discourse. that was promised immunity but was destroyed and its inhabitants expelled despite their overtures of peace. Hadari employs the same tone when discussing the army's policy of shooting villagers trying to return to their villages after having been expelled.As with other such actions, he treats it as a purely military problem. Hadari has high praise for the IDF's "de-Arabization" of the Galilee from May to October 1948. (Interestingly, while the term "ethnic cleansing" is almost never used by the neo-Zionists, the term "de-Arabization" has been adopted; yet in pre-1948 classical Zionist discourse, Arabs were rarely even mentioned and such a term would have been unthinkable. The land, after all, was basically "empty," and the task was therefore to colonize. Only a few overtly acknowledged that colonization required removal of the local population.) 
Among the numerous other examples of the neo-Zionist tendency to recount events unapologetically that earlier would have aroused at the very least uneasiness (or simply been omitted), I will briefly mention only a few.The writer Uri Milstein, for instance, describes in detail the massive looting of Palestinian houses, but uses the phenomenon not to criticize the acts themselves but to expose the Haganah's disorganization and failure to coordinate. ${ }^{42}$ Two chapters in the Kadish volume are also good examples of the neo-Zionist treatment of the systematically aggressive policy of the Zionist forces toward the Palestinian or mixed towns, where they premeditatedly drove out the Palestinian inhabitants. The chapter by Yoav Peleg ${ }^{43}$ on the April 1948 operations in Jaffa corroborates the New Historians' finding that the military confrontation in the town and the expulsion of its fifty thousand Arabs could have been avoided but that Haganah commanders did not want the Arabs to remain. A similar picture emerges from Moshe Arnewald's chapter depicting the expulsion of the Palestinian population of West Jerusalem during the same period. ${ }^{44}$

Both researchers find this policy acceptable and neither shows any sign of the moral reservations typical of the New Historians. For example, the final pages of Peleg's article describe how the Irgun carried out its operation to "cleans[e] enemy outposts" by "relentlessly bombard[ing] the Ajami quarter and the other Arab neighborhoods of the town center with the objective of breaking the inhabitants' morale and creating chaos and havoc to cause mass flight." ${ }^{45}$ The objective of the Jewish plan to take over West Jerusalem as recounted by Arnewald is identical:"to cause a flight from the Arab neighborhoods outside the Old City and the concentration of the Arab population in it." ${ }^{46} \mathrm{He}$ comments that as a result of the attacks, "the population density of the Old City by May 1948 was unbearable," its original population having doubled or even tripled. ${ }^{47}$ Despite the "gravity" of the living conditions and hygienic situation, and although "on 8 May typhus broke out and riots began due to the scarcity of food and flour," he claims that the population there felt secure. ${ }^{48}$ In fact, the Old City population with its refugees did remain, but virtually the entire Arab population of west Jerusalem was driven out as a result of these actions.

Many (if not most) of Kadish's authors focus either on military operations or dimensions having a decisive impact on the direction of the war, or on prominent issues in the debate over 1948. By comparison, Aharon Klein's topic ${ }^{49}$ - the 1948 prisoners of war (POWs) - was little more than a sideshow. Still, it is useful to spend some time on his chapter as it is illustrative of many of the characteristics of the neo-Zionist historians we have been discussing. Klein had access to the IDF files released on the POWs and his findings largely confirm those of Salman Abu Sitta's study, ${ }^{50}$ which was based solely on oral histories and relevant reports from the International Red Cross (IRC) archives (Klein cites the IRC archives and Abu Sitta among his sources). In Abu Sitta's account, the POWs were mostly citizens of the new state under international law who were not only imprisoned but also ethnically cleansed in that they were permanently uprooted from their villages but permitted to remain within 
Israel's borders. About five thousand of them were exposed to forced labor and systematically harassed. ${ }^{51}$

Klein, who accepts Israeli policy toward the 1948 POWs as unavoidable, notes in passing that intelligence officers had permission to decide on the spot which Palestinians captured in military operations could be executed immediately - a reference that corroborates Palestinian oral recollections of summary executions in occupied villages and neighborhoods throughout Palestine. Although he does report cases of barbarism and executions in the POW camps themselves, he states that these were not the norm and attributes excesses to the major logistical problems inevitable when thousands of men are taken prisoner. In his section on the "Guards of the Camp" (Shomeri Hamahanot),${ }^{52}$ he also notes that most of the camp guards were members of the Stern group and the Irgun, suggesting that if exceptional brutality occurred it came from the "extreme right." 53

According to Klein, anyone over the age of ten who appeared suspicious was a legitimate POW, and the troops were ordered to seize as many POWs as possible. ${ }^{54}$ While not directly expressing misgivings about the tender age of the child POWs-whom he sometimes refers to as "children" and sometimes as "soldiers" - he does appear to want to fend off potential criticism. Thus, we are given the rather extraordinary explanation that small children were captured as POWs only after their mothers had been expelled. This is undoubtedly true, since the Zionist forces separated all male children and adolescents above the age of ten from their mothers before expulsion as a matter of course, ${ }^{55}$ but the implication here seems to be that the capture and imprisonment of very young children was a humanitarian act to save them from being left on their own.

With regard to the entire concept of forced labor, Klein commends the Israeli army for its efficient and purposeful use of the prisoners who fell into their hands. Most of the prisoners were Palestinian teenagers and young men in their early twenties, not soldiers, and were employed in hard labor. ${ }^{56}$ The following passage about the construction of labor camps-based on an IDF document that never would have been made available to critical scholars-is a good illustration of neo-Zionist historiography's bland, matter-of-fact, technocratic approach, which contrasts so sharply with the moral indignation that such information would have occasioned in post-Zionist scholars even when not made explicit in their historical texts.

The occupational potential present in thousands of Arab POWs was enormous. The Israeli market suffered from a serious deficit in working hands and the military system was in urgent need of new [military] bases and many camps. [Furthermore, t]he realization that employing the POWs would solve some of the problems and needs of the IDF led to the decision to build two special labor camps for captives-one in Sarafand and the other in Tel-Littwinski [Tel-Hashomer hospital today]. 
The building of the camps was completed in September 1948 . Another special labor camp was opened for several months in Umm Khalid near Netanya.... The construction of labor camps was a significant quantum leap in the exploitation of manpower within the POWs, whose numbers kept growing. ${ }^{57}$

Finally, Klein commends the army for introducing order into the system and implies that the situation was beyond their control:"Although the young military system of the IDF was not prepared for this affair ... it succeeded in organizing itself in a reasonable manner and solving satisfactorily the problem of the prisoners." 58 By the end of October/early November 1948, the employment of POWs was systematized, backed by procedures, orders, forms, and reports. Nowhere in Klein's account is there any hint about the horrors described in the following first-hand account recorded in the immediate aftermath of the war by a Palestinian survivor:

We were loaded into waiting trucks.... Under guard we were driven to Um Khalid ... and from there to forced labor. We had to cut and carry stones all day. Our daily food was only one potato in the morning and half a dried fish at night. They beat anyone who disobeyed orders.After 15 days they moved 150 men to another camp. I was one of them. It was a shock for me to leave my two brothers behind.As we left the others, we were lined up and ordered to strip naked.To us this was most degrading. We refused. Shots were fired at us. Our names were read we had to respond 'Sir' or else. We were moved to a new camp in Ijlil village. There we were put immediately to forced labor, which consisted of moving stones from Arab demolished houses. We remained without food for 2 days, then they gave us a dry piece of bread..$^{59}$

Klein says little about the camp conditions other than that the prisoners were well fed and paid for their work. ${ }^{60}$ As reference for this latter claim, he quotes an IDF document summarizing what the army told a delegation of the IRC, making no mention that the IRC documents, which juxtapose the IDF report with the testimonies of the inmates, give exactly the opposite impression. ${ }^{61}$ But at least Klein does not present the camp experience as something positive for those who lived through it.This is in contrast to the volume's editor, who in his general introduction to the collection comments with regard to Klein's article that "some of them [the Palestinian POWs] must have been happy since they sometimes worked in places where they had earlier been employed by the British." ${ }^{62}$

The neo-Zionist historiographical paradigm has now also been introduced into Israel's educational system. In the late 1990s, two textbooks hinting at the possibility of Palestinian expulsions in 1948 were under consideration for inclusion in the national curriculum, but after heated debate in the Knesset 
Education Committee, they were rejected. But what was taboo in 1999 has become legitimate since 2000 , and the education ministry's official curriculum now uses a book that teaches pupils that the Israeli army began expelling Palestinians and destroying their villages to prevent their return about a month and a half into the war. Given that the war is officially seen as having begun on 15 May when the Arab armies entered Palestine (the implementation of Plan Dalet is not considered part of the "war"), a month and a half into the war would be early July. ${ }^{63}$ Even leaving aside the rather extraordinary explanation that the expulsions were initiated because the population was no longer leaving voluntarily, there is no historical data to support this version; in fact, all of the evidence presently available in the IDF archives attests to systematic expulsions having depopulated more than three-quarters of the refugees by July. What is interesting, however, is that the expulsions are now unambiguously acknowledged in the school curriculum.

After thoroughly examining the history, geography, and civics textbooks addressing the 1948 war that are part of the curriculum, educationalist Daniel BarTal concludes that the Zionist view of the conflict predominates and that the works convey an image of Jewish victimhood and a negative stereotyping of the Arabs. ${ }^{64}$ Other authors corroborate the finding that Zionism pervades the history dealing with $1948 .{ }^{65}$

\section{CONCLUSION}

The transformation in the Zionist discourse is well illustrated by juxtaposing two quotes from Anita Shapira with regard to the expulsion of the Palestinians. In a 1999 article in the New Republic, she wrote:

The Arab panic led to an exodus and to the collapse of the institutions of Palestinian society. The more the magnitude of the exodus became clear, the more admissible and attractive the idea seemed to Israeli leaders and military commandersnot because the Zionist movement had been planning such an evacuation all along but because a remote option (even if there were some who harbored such hankerings) gained acceptance in the context of the behavior of both sides during the war. ${ }^{66}$

Five years later, the Arab exodus depicted by Shapira as a "remote option" barely contemplated by the Israeli political and military leadership as late as spring 1948 (even though some may have "harbored hankerings" for it) could suddenly be presented concretely and no longer qualified as contingent on the behavior of the Arab side. In her 2004 biography of Yigal Allon, for example, Shapira wrote that he "was the most consistent supporter of transferring the Palestinians and even committed massive expulsions in the war of independence." ${ }^{67}$ She also approvingly quotes Allon's statement at a public lecture in 1950 that an "eternal justification" (i.e., the eternal right 
of the Jewish people to a homeland without "aliens") validated the massive expulsions of Palestinians. To this, she added that "He did his best not only to occupy the land of Israel, but also to depopulate it." ${ }^{68}$ The extent of the official or mainstream embrace of the reality of the expulsions as something positive, a necessary prelude to attaining Jewish rights, is also well illustrated by the fact that the website for the virtual library of Israel's Centre for Educational Technology, a government agency supervised by the ministries of education and culture, carries numerous references to the expulsions of the Palestinians in 1948.

In yet another example of facts denied in the past and now embraced, in the late 1990s, the New Historians had successfully demolished the characterization of the 1948 war as a Jewish David against the Arab Goliath, a myth that was crucial for developing both contempt for Arabs and Palestinians and for cultivating a sense of invincibility of almost metaphysical proportions. At the beginning of the twenty-first century, the IDF released two documents revealing that the Israeli forces had a military advantage of two to one during the 1948 war, a fact now widely accepted but presented in a way that strengthens rather than weakens faith in this mythology. The following quote from Leah Segal of the neo-Zionist school of thought is a good illustration.

[These documents] teach us that 1948 was not a war of the few against the many. This is an undeniable fact today. But why do people claim that it debunks the myth of the few against the many? How did an army representing 65,000 people defeat armies that represented 35 million people?' The answer is it was "a war between quality and quantity." 69

Any other interpretation, she adds, is from the school of historians such as Ilan Pappé and Avi Shlaim, who willingly became the spokespeople of Palestinian propaganda.

The transition in Israel from a hopeful period of peace to the pessimism of war has been reflected in professional historiography and ideological debates within Israeli Jewish society. I have described this vacillation as ranging from a post-Zionist position critical of Israel's past and present conduct (sometimes to the point of questioning the legitimacy and moral validity of the Zionist ideology) to a neo-Zionist position still strongly adhering to the basic tenets of classical Zionist ideology. Ideology's powerful hold on historiography was already evident in the early 1990s, when the scholarly debate in Israel regarding what happened in 1948 was conducted not only on the academic stage but even more so in the public arena, where a discourse of patriotism and humanism was often employed to justify both positions.

The reason why the professional Israeli historiography of 1948 is such a clear example of the biased nature of the historiographical enterprise is due to 1948's central role in the national narratives of both Palestinians and Israelis. That year is seen as a miraculous year by the Zionist movement and as a cataclysmic catastrophe by the Palestinians, having produced both the State of 
Israel and the Palestinian refugee problem. Both issues will remain open as long as the conflict continues.

A review of the reversals of fortune of post-Zionism and the ascendance of neo-Zionism in the research on 1948 can serve three purposes. First, it can demonstrate once more how ideology impacts the production of professional historiography in agitated societies such as Israel. Second, it can provide a barometer of the present intellectual and cultural orientation of Jewish society in Israel, often neglected at the expense of the near exclusive focus on government policies and military strategies as the only factors determining a state's position vis-à-vis a given reality. Finally, it confirms once again that the struggle over memory will remain a crucial factor in shaping the conflictual reality of Israel and Palestine and will impact the chances of reconciliation in the future.

As a final footnote, I would add that the currently prevailing consensus in Israel justifying whatever happened during the 1948 war has far-reaching political implications. It reveals an Israel unwilling to reconcile with the past and with the Palestinians, an Israel overconfident that its policies of ethnic cleansing and dispossession can be morally justified and politically maintained as long as there are Western academics and politicians who are reluctant to apply the same set of values and judgments to the Jewish state that they have applied, quite brutally, to countries in the Arab and Muslim world.

\section{NOTES}

1. Louis Althusser, Essays on Ideology (London:Verso Books, 1984).

2. See, for example, Michal Bar-Josef Hirsch, "From Taboo to the Negotiable:The Israeli New Historians and the Changing Representation of the Palestinian Refugee Problem," Perspectives on Politics 5, no. 2 (June 2007), pp. 241-58 and Avi Shlaim, "The New Historians of the Middle East," Oxford Today 20, no. 1 (Michaelmas 2007), http://www.oxfordtoday.ox.ac uk/2007-08/v20n1/04.shtml.

3. Their impact in the areas of historiography, the media, and education was discussed by this author in a series of three articles in the Journal of Palestine Studies in the late 1990s.

4. Ilan Pappé, "The Post-Zionist Discourse in Israel, 1991-2001," Holy Land Studies 1, no. 1 (2002), pp.3-20.

5. Ilan Gur-Ze'ev and Ilan Pappé, "Beyond the Destruction of the Other's Collective Memory: Blueprints for Palestinian/Israeli Dialogue," Theory, Culture E Society 20, no. 1 (Feb 2003), pp. 93-108.

6. See Yoav Gelber, Independence versus Nakba:The Arab-Israeli War of
1948 [in Hebrew] (Or Yehuda: Dvir, 2004).

7. See, for example, Tuvia Friling, ed., An Answer to a Post-Zionist Colleague [in Hebrew] (Tel-Aviv:Yediot Acharonot Publication-Hemed Books, 2003).

8. Daniel Pilser, "Making History" [in Hebrew], Techelet (9 March 2000), p. 1. All quotes in this article taken from books and articles written in Hebrew were translated into English by Ilan Pappé.

9. Pappé, "The Post-Zionist Discourse in Israel."

10. Efraim Karsh, Fabricating Israeli History: The 'New Historians' (London and New York: Routledge, 2000).

11. Pilser, "Making History," p. 1.

12. Anita Shapira and Derek J. Penslar, eds., Israeli Historical Revisionism: From Left to Right (London and Portland: Frank Cass Publishers, 2003), p. iv-vi.

13. Michael Walzer,"History and National Liberation," in Shapira and Penslar, eds., Israeli Historical Revisionism, pp. 1-8.

14. Michael Walzer, "History and National Liberation,” p. 8. 
15. Daniel Gutwein, "Left and Right Post-Zionism and the Privatization of Israeli Collective Memory," in Shapira and Penslar, eds., Israeli Historical Revisionism,pp.9-42.

16. Martin Kramer, Ivory Towers on Sand:The Failure of Middle Eastern Studies in America (Washington:The Washington Institute for Near East Policy, 2001) and Gelber, Independence versus Nakba.

17. Benny Morris, "Survival of the Fittest," interview by $\mathrm{Ha}^{\prime}$ Aretz reproduced in Journal of Palestine Studies 33, no. 3 (Spr. 2004), p. 168.

18. Morris, "Survival of the Fittest," p. 169

19. Morris, "Survival of the Fittest," p. 168.

20. For example in Gili Haksin, "The Historiographical Development of Israel's Creation and the Conflict with the Arabs" [in Hebrew] (PhD thesis, Haifa University, 2007) and Moshe Shalem, "The Hagana Value System-A Historical Examination of Their Formation and Dissemination, 1939-1948" [in Hebrew] (PhD thesis, Bar-Ilan University, 1997).

21. See, for example, Eli Eyal, ed., "The War of Independence-Special Issue" [in Hebrew], Kivunim Hadashim 14 (June 2006).

22. Alon Kadish, ed., Israel's War of Independence 1948-1949, 2 vols. [in Hebrew] (Tel-Aviv: Israeli Ministry of Defense Publication, 2004), pp. 11-13. The Hebrew title uses the Jewish calendar reference. p. 14.

23. Kadish, Israel's War of Independence,

24. Mordechai Bar-On, A Memory in A Book: The Early Israeli Historiography of the War of Independence, 1948-1958 [in Hebrew] (Tel-Aviv: Israeli Ministry of Defense Publication, 2001), p. 60.

25. Morchechai Bar-On and Meir Hazan, eds., People at War, Research on the Civil Society in the War of Independence [in Hebrew] (Jerusalem:Yad Ben Zvi, 2007).

26. In an article in the Guardian dated 14 May 2009, Morris writes: "The simple truth is that since before its inception, the Arab world has laid siege to the Zionist enterprise and tried to destroy or badly weaken it, in war after war..." The first such war was 1948, depicted as an Israeli act of self-defense due to Palestinian and general Arab hostility. In his book, Righteous Victims: A History of the Zionist-Arab Conflict, 1881-2001 (New York:Vintage, 2001), he goes further, blaming the Palestinians for causing the Zionists to deal with them brutally at times, especially in 1948. According to him, it was the Palestinian Muslims, and more generally their primitive culture, that left the Zionist movement little choice in 1948. In his 2008 book, 1948: A History of the First Arab-Israeli War (New Haven and London:Yale University Press), Morris describes the Palestinian and Arab attacks on the Jewish state in 1948 as "Jihaddist," which is another way of putting blame on the Palestinians.

27. In an article in the History News Network dated 17 June 2002 and titled "Why Did the Palestinians Run Away in 1948?" for example, Gelber writes that the 1948 war began because of the Palestinian rejection of the partition resolution and the Arab world's wish to destroy the Jewish state. In his view, whatever the Jewish forces did was in total, morally justified self-defense.

28. Tamir Goren, "Separate or Mixed Municipalities? Attitudes of Jewish Yishuv Leadership to the Mixed Municipality during the British Mandate:The Case of Haifa," Israel Studies 9, no. 1 (Spr. 2004), p. 101-24.

29. Yakob Markovizky, "The GahalRecruitment Abroad in the War of Independence" [in Hebrew], in Kadish, ed., Israel's War of Independence, pp. 525-38.

30. Alon Kadish,"Settlements Prepare for War" [in Hebrew], in Kadish, ed., Israel's War of Independence, pp. 801-48.

31. Jonathan Fine, "Basic Problems in Government and Logistics" [in Hebrew], in Kadish, ed., Israel's War of Independence, pp. 679-710 and Amir Bar-Or, "The War of Independence:The Supervision of the Political Institutions over the Hagana Organization" [in Hebrew], in Kadish, ed., Israel's War of Independence, pp. 711-58.

32. Haim Barkai, "The Real Cost of the War of Independence" [in Hebrew], in Kadish, ed., Israel's War of Independence, pp. 759-92 and Yitzhak Greenberg, "The Impact of the Economic Consideration on the Crucial Stages of the War of Independence" [in Hebrew], in Kadish, ed., Israel's War of Independence, pp. 793-800.

33. Yehuda Wallach, The Carta Atlas for the War of Independence-Operations, 
Sites of Battles, Commemoration Sites [in Hebrew] (Tel-Aviv: Carta, 2005); Lea Abunil, "Qawqji's Salvation Army" [in Hebrew] (MA thesis, Bar-Ilan University, 2005); and David Tal, War in Palestine, 1948: Strategy and Diplomacy (London and New York: Routledge, 2004).

34. Moshe Naor, Fire on the Carmel: The Palmach Operations against the British Radar Stations, 1945-1947 [in Hebrew] (Tel-Aviv: Ministry of Defense Publication, 2006).

35. Arnon Golan, "The Reshaping of the Ex-Arab Space and the Construction of an Israeli Space (1948-1950)" [in Hebrew], in Kadish, ed., Israel's War of Independence, p. 912.

36. Titled 'The Transformation of the Settlement Map in the Areas Abandoned by the Arab Population as a Result of the War of Independence in the Territory on Which the State of Israel Was Founded, 1948-1950" [in Hebrew] (University of Haifa, 1993)

37. Morris's post-2000 regrets are expressed, among other places, in the above-mentioned 2004 Ha'Aretz interview and in his book 1948.

38. See Morris, "Survival of the Fittest" and Morris, 1948.

39. Dani Hadari, "The War of Independence in the North" [in Hebrew], in Kadish, ed., Israel's War of Independence, pp. 119-70.

40. Hadari, "The War of Independence in the North," p. 131.

41. Hadari, "The War of Independence in the North," p. 133.

42. Uri Milstein, "The Looting by Harel," NEWS1, 28 February 2005. Milstein, who comes from the right of the political map, is an intriguing historian who seeks to undermine the heroic image of the Labor Zionist commanders of the 1948 war, particularly Yizhak Rabin.

43. Yoav Peleg, "The Campaign in Jaffa and the Surrounding Area" [in Hebrew], in Kadish, ed., Israel's War of Independence, pp. 389-422.

44. Moshe Arnewald, "The Military Campaign in Jerusalem in the War of Independence, November 1947-April 1949" [in Hebrew], in Kadish, ed., Israel's War of Independence, pp. 341-88.

45. Peleg, "The Campaign in Jaffa," p. 417.

46. Arnewald,"The Military Campaign in Jerusalem,” p. 362.
47. Arnewald,"The Military Campaign in Jerusalem," p. 359.

48. Arnewald,"The Military Campaign in Jerusalem," p. 359.

49. Aharon Klein, "The Arab POWs in the War of Independence" [in Hebrew], in Kadish, Israel's War of Independence, pp. 567-86.

50. Salman Abu Sitta, Report to Israeli Web Site Zochrot [in Hebrew], 19 May 2002, www.zochrot.org/ index.php?id=70.

51. See Abu Sitta's research in Ilan Pappé, The Etbnic Cleansing of Palestine (Oxford: Oneworld Publications, 2006), pp. 200-04.

52. The insensitivity displayed in Klein's choice of subtitles, which would send shivers up the spine of any Holocaust survivor, could be the result of the overuse, abuse, and manipulation of the Holocaust memory in Israel, or simply ignorance. His use of the term Mabanot Haavoda (the labor prison camps) in Klein, "The Arab POWs," p. 577, shows a similar insensitivity.

53. Klein, "The Arab POWs," p. 575.

54. Klein, "The Arab POWs," p. 568.

55. Ilan Pappé, "The Tantura Case in Israel:The Katz Research and Trial," Journal of Palestine Studies 30, no. 3 (Spr. 01), pp. 23-25.

56. Klein,"The Arab POWs," p. 568, 576.

57. Klein, "The Arab POWs," p. 576.

58. Klein, "The Arab POWs," p. 583.

59. Nimr al-Khatib, Palestine's Nakba (Damascus, 1950), p. 116.

60. Klein, “The Arab POWs," p. 580

61. Klein's lack of interest in POW testimonies is perhaps not surprising, but this is the only study I have ever seen about POWs that totally disregards the testimonies of the prisoners themselves. Imagine reconstructing life in a concentration camp without the oral and written testimonies of the inmates.

62. Kadish, Israel's War of Independence, p. 24 .

63. This is the basis of the argument also made in Yoav Gelber's book, Independence versus Nakba, which inspired the curriculum choice.

64. Daniel Bar-Tal, Living with the Conflict, Socio-Psychological Analysis of the Jewish Society in Israel (Jerusalem: Carmel, 2007), p. 443.

65. See, for example, Sami Adwan and Ruth Firer, The Narrative of the 
Palestinian Refugees during the War of 1948 in Israeli and Palestinian History and Civic Education Textbooks (Paris:

UNESCO Publications, 1997).

66. Anita Shapira, "The Past Is Not a Foreign Country:The Failure of Israel's 'New Historians' to Explain War and Peace," The New Republic Online, 29 November 1999, http://ontology.buffalo. edu/smith/ courses01/rrtw/Shapira. htm.

67. Anita Shapira,Yigal Allon:A Biography [in Hebrew] (Tel-Aviv:Am Oved, 2004), p. 152.

68. Shapira, Yigal Allon, p. 152.

69. Leah Segal,"Between Myth and Reality: Few against Many?" [in Hebrew] Hazofeh (24 February 2007), p. 2. 